\title{
Heretic or rebel? The heresy trial of Albert Geyser
}

\begin{tabular}{|c|c|}
\hline \multicolumn{2}{|l|}{$\begin{array}{l}\text { Author: } \\
\text { Wim Dreyer }\end{array}$} \\
\hline \multicolumn{2}{|c|}{$\begin{array}{l}\text { Affiliation: } \\
{ }^{1} \text { Department Church History } \\
\text { and Church Polity, University } \\
\text { of Pretoria, South Africa }\end{array}$} \\
\hline \multicolumn{2}{|c|}{$\begin{array}{l}\text { Project leader: W.A. Dreyer } \\
\text { Project number: } 77370920\end{array}$} \\
\hline \multicolumn{2}{|c|}{$\begin{array}{l}\text { Description: } \\
\text { This research is part of the } \\
\text { project, 'History of the } \\
\text { Netherdutch Reformed } \\
\text { Church/Geskiedenis van die } \\
\text { Nederduitsch Hervormde } \\
\text { Kerk', directed by Dr Wim } \\
\text { Dreyer, Department of } \\
\text { Church History and Church } \\
\text { Polity, Faculty of Theology, } \\
\text { University of Pretoria. }\end{array}$} \\
\hline \multicolumn{2}{|c|}{$\begin{array}{l}\text { Corresponding author: } \\
\text { Wim Dreyer, } \\
\text { wim.dreyer@up.ac.za }\end{array}$} \\
\hline \multicolumn{2}{|c|}{$\begin{array}{l}\text { Dates: } \\
\text { Received: } 14 \text { July } 2016 \\
\text { Accepted: } 11 \text { Aug. } 2016 \\
\text { Published: } 25 \text { Nov. } 2016\end{array}$} \\
\hline \multicolumn{2}{|c|}{$\begin{array}{l}\text { How to cite this article: } \\
\text { Dreyer, W., 2016, 'Heretic or } \\
\text { rebel? The heresy trial of } \\
\text { Albert Geyser', HTS } \\
\text { Teologiese Studies/ } \\
\text { Theological Studies 72(4), } \\
\text { a3745. http://dx.doi. } \\
\text { org/10.4102/hts.v72i4.3745 }\end{array}$} \\
\hline \multicolumn{2}{|c|}{$\begin{array}{l}\text { Copyright: } \\
\text { (C) 2016. The Authors. } \\
\text { Licensee: AOSIS. This wo } \\
\text { is licensed under the } \\
\text { Creative Commons } \\
\text { Attribution License. }\end{array}$} \\
\hline \multicolumn{2}{|l|}{ Read online: } \\
\hline 口4da & $\begin{array}{l}\text { Scan this QR } \\
\text { code with your } \\
\text { smart phone or } \\
\text { mobile device } \\
\text { to read online. }\end{array}$ \\
\hline
\end{tabular}

During September 1961, a charge of heresy was laid against New Testament scholar and antiapartheid activist Prof. A.S. (Albert) Geyser. The charge was brought by three senior theological students of the University of Pretoria. They accused Geyser of interpreting Philippians 2 in such a way that it undermined the church's doctrine of Christ's pre-existence. The heresy trial started on 24 October 1961 under massive public interest. The trial lasted 6 months and the proceedings covered 2672 typed pages. Reporters of 25 national and international newspapers attended the trial. The heresy trial caused widespread international condemnation of what was regarded as an orchestrated attempt to get rid of Geyser, because of his public and radical opposition to apartheid. In this contribution, Geyser's theological critique of apartheid as well as his conviction of heresy is discussed. The proceedings of the trial, minutes of the moderature, media coverage and Geyser's publications serve as primary sources. It concludes with a critical evaluation of Geyser's theology and his role as a public theologian.

\section{Introduction}

On 1 May 2015, Prince Mashele wrote an article in the Sowetan (Sowetan Live 2015) on the defacing of statues in South Africa, in which he said the following of Prof. A.S. (Albert) Geyser:

\begin{abstract}
Here was a white man, an Afrikaner by blood, adhering obstinately to a biblical truth that essentially shattered the religious foundations of Afrikanerdom - his very own being. It would indeed be difficult to know the extent to which black anti-statue crusaders of our time value truth. But it is easy to understand why white people have built no monument to Geyser. Could it be that those who are busy defacing statues are themselves not different from the very statues they seek to eradicate? True virtue is not when a man defends his own interests, but when he endangers his life in defence of others. This is precisely what Geyser did. It is time for us, black people, to wage a 'Geyser must rise' campaign to protect the legacy of a white man who proclaimed that blacks were human at a time when such a basic truth was heresy. (n.p.)
\end{abstract}

Heresy trials have become something of a rarity in modern times. This fact alone would have made the trial of Prof. Albert Geyser, which lasted 6 months (1961-1962), remarkable. However, the events surrounding the trial present us with a rare insight in the complex and volatile history of South Africa just after it left the British Commonwealth and became a sovereign republic under the leadership of Dr H.F. Verwoerd as prime minister.

It is also remarkable if we consider who Geyser was (see Dreyer 2015:187-189). Albertus Stephanus Geyser was born on 10 February 1918 on a farm close to Naboomspruit (Mookgophong), the heartland of Afrikaner conservative politics and a typical farming community. His father and mother were devout members of the Nederduitsch Hervormde Kerk van Afrika (NHKA). He was one of three children. After he matriculated in 1935, Geyser and his brother started their theological studies at the University of Pretoria during 1936. He eventually completed a MA (Classical Languages) in 1942 and had a sound knowledge of Hebrew, Syriac, Aramaic, Greek, Latin, French, German, Dutch and English. Including Afrikaans, he could read 10 languages. In 1941 Geyser was ordained as a minister in the NHKA Heilbron, a small town in the Free State. In 1944 he was called to a congregation in Pretoria where he served until 1946. At various periods he took leave to assist the congregation in Cape Town.

Geyser started with doctoral studies in Church History. He changed to New Testament during 1944 and within a year Geyser finished the doctoral exams and on 15 March 1946 he received the degree Doctor Divinitatis (Cum Laude). His external examiner was Prof. J. De Zwaan of the University of Leiden. At the beginning of 1946, at the young age of 27, Geyser was appointed as a lecturer in the Department of New Testament Studies at the University of Pretoria. Later that same year, he was promoted to a full-time professor and Head of the Department. He remained in this position until 1961, a period of 15 years. After the heresy trial he accepted a position at the University of the Witwatersrand. Albert Geyser was also the first SA New Testament scholar 
elected as the member of the Studiorum Novi Testamenti Societas and served as the editor of Novum Testamentum. He must also be remembered for the high standards that he set for his own academic career. He obtained three master's degrees in Greek, Latin as well as French. He translated Thomas á Kempis's classical work De Imitatio Christi into Afrikaans (Geyser 1952).

In this contribution Geyser's theological critique of apartheid as well as his conviction of heresy is discussed. The proceedings of the trial, minutes of the Moderature, media coverage and Geyser's publications serve as primary sources. This paper concludes with a critical evaluation of Geyser's theology and his role as public theologian.

\section{Geyser's critique of apartheid}

Prof. P.G.R. de Villiers (Van Aarde, De Villiers \& Buitendag 2014:3) is of the opinion that Geyser's theological criticism and rejection of apartheid had a seminal influence on white South Africans who were opposed to apartheid. It also caused a lot of animosity among fellow lecturers at the University of Pretoria as well as the general public. Geyser's opposition to apartheid, at a time when it was regarded by many as a scriptural principle and the only guarantee for the survival of white people in Africa, resulted in his complete isolation (Van Aarde et al. 2014:4-5) and a feeling among some church leaders that Geyser had to be removed from his position. A charge of heresy could accomplish this.

Geyser's opposition to apartheid had much to do with his teaching stints at the Sorbonne (1949) and University of Utrecht (1952), contact with the international ecumenical movement and interaction with leading European theologians such as Karl Barth, Oscar Cullmann and Hendrikus Berkhof. His opposition to apartheid also stems from the fact that he was a firm supporter of the South African Party of Genl. J.C. Smuts (see footnote in Van Aarde et al. 2014:4-5). Smuts was well-known for his philosophy of 'Holism'. As a supporter of the SAP and opposed to the National Party of D.F. Malan's policy of institutional and legal segregation, Geyser had the support of many like-minded members and ministers of the NHKA, the English press in South Africa, Dutch colleagues such as Van Selms and Gemser as well as Afrikaans academics such as S.P. Engelbrecht (who later turned against Geyser), C.J. Labuschagne, B.B. Keet and B.J. Marais. After the Geyser trial, many of his supporters left the NHKA.

By 1955 (age 37) Geyser had become outspoken in his criticism of apartheid. A clear indication of this was his opposition to the removal of mixed race people from the voters' roll, after the Senate had been enlarged by parliament to give the National Party the majority vote. Geyser and a colleague from the NHKA, the well-known church historian Prof. S.P. Engelbrecht as well as 11 other Afrikaner academics, signed a petition condemning the orchestrated actions of the ruling party in parliament. This happened during a public protest meeting, held on 16 May 1955. This aroused much resentment within the church, to such an extent that the
Moderature of the NHKA released a media statement, rejecting the views of Geyser and Engelbrecht in the strongest terms (see Oberholzer 2010). ${ }^{1}$ This was followed with several disciplinary meetings, which continued until the end of 1955. Eventually it was agreed from both sides not to proceed with disciplinary or legal actions, after Geyser and Engelbrecht gave the assurance that it was not their intention to bring the church into disrepute or become involved in party political actions, but rather exercised their responsibility to public witness. Engelbrecht, however, continued to sue Die Transvaler for libel to an amount of $£ 2000$.

Geyser's opposition to apartheid became more intense during 1960. There were several reasons for this: Firstly, the Sharpeville massacre (21 March 1960) sent shock waves through South Africa and the rest of the world. Secondly, the World Council of Churches (WCC) planned a meeting during December 1960 in Cottesloe (Johannesburg), where all the member churches would present their views on the situation in South Africa and to formulate a common witness against racism. Thirdly, South Africa's departure from the British Commonwealth under the leadership of Dr. H.F. Verwoerd was on the cards and became a reality on 31 May 1961. As such, 1960 became a pivotal year for Geyser's resistance against apartheid.

Geyser started organising meetings of clergy he knew would oppose apartheid. These meetings of clergy became known as the Ekumeniese Studiekring. It eventually evolved into the Christelike Instituut, of which Dr. Beyers Naude was the director and Geyser the chairman of the Board. Members of the Studiekring produced several documents, newspaper articles and publications in which they criticised the policy of apartheid (see Dreyer 2015:188-191). Geyser and 10 other theologians also published a booklet (Geyser \& Keet (ed.) 1960) with the title Vertraagde Aksie, translated as Delayed Action. In this compilation of theological essays, direct or indirect criticism was directed against the government and church policies of segregation. The 11 authors who contributed to the publication were A.S. Geyser, A. van Selms, M.J. Redelinghuys and J. Stutterheim (clergy from the NHKA); B.B. Keet, B.J. Marais, G.C. Oosthuizen, J.A. van Wyk and G.J. Swart (clergy from the Dutch Reformed Church, or DRC), as well as H. du Plessis and C. Hattingh (clergy from the GKSA).

In Vertraagde Aksie (Geyser 1960:12-23), Geyser did not address the issue of apartheid by name, but rather the question of various ethnic churches which were established through the missionary work of the white churches. He emphasised the basic ecclesiological principle of church unity and its powerful witness to the world. At a time when the DRC became known as 'the National Party in prayer', criticism of ecclesial segregation had direct political implications.

In Geyser's contribution in Vertraagde Aksie, we find a very specific ecclesiology and understanding of what it means to

1.'Die Kerk betreur ten seerste die optrede van die twee professore wat hulle daardeu verbind het aan'n party-politieke agitasie en so die verantwoordelikheid van hul hoë betrekking verontagsaam het' 
be church. In a previous article, the influence of Karl Barth on Geyser's ecclesiology was discussed (Dreyer 2015:188-189). We also find very clear traces of an ecumenical ecclesiology, especially his reference to John 17 (Geyser 1960:17). Geyser challenged his readers with the nature of the church, because if we understand the true nature of the church it has radical implications for the way the church speaks and engages with society. By entering the discourse via ecclesiology and placing the focus on the true nature of the church, it is clear that Geyser followed the same strategy as Karl Barth in his opposition to the Nazi ideology in Germany before World War II.

Geyser starts his contribution in Vertraagde Aksie with a historical overview of Early Church history, with specific reference to the persecution of 'the people of the Way' (Geyser 1960:12). He points out that the earliest persecutors of the church knew that the most powerful Christian witness was not so much Christian preaching, ethics or confession but rather the very nature of the church. Whenever the church is true to its own nature and the integrity of the church stands foremost, the church as such becomes the most powerful witness to the gospel of Jesus Christ. The Christians were persecuted not because of what they said or what they did, but because of what they were - the church of Christ.

Geyser (1960:13-14) then enters into a discussion of the confession: 'Credo unam sanctam catholicam ecclesiam'. He points out that the 'una' is often mistakenly translated not as 'one' church but as 'a' church. The church of Christ is one the most basic point of departure in our understanding of the church is that its members are one in Christ and that unity should become manifest amongst the individual members of the church. Geyser further points out that the other essential qualities of the church ('sanctam' and 'catholicam') are fundamentally determined by 'unam'. The church is holy and catholic because of its unity in Christ.

Geyser (1960:14) continues by explaining the word 'kuriakon', as meaning 'what belongs to the Lord'. From this he comes to the conclusion that it is impossible to speak of an Afrikaans church, a Dutch church or a Bantu church. He points out that in the midst of ethnic, political and geographical divisions the church must be one as one, new humanity which belongs to God. From this it is quite clear that Geyser's ecclesiology stood diametrically opposed to segregation in church and state.

Geyser (1960:14-21) then enters into a long discussion of the word 'ekklesia'. He highlights the meaning of the word with reference to the gospels, early church fathers such as Chrysostomos, Augustine, Cyprian and even the third century Pope Callixtus. In his exegesis Geyser emphasises the communal character of the 'ekklesia', of the church. The church are those people, of all nations, who were called by the Lord and sent out by the Lord (Mt 28). From this Geyser (1960:16-17) enters into a discussion of mission, where it is again evident that he followed Barth's understanding of mission, as articulated at the Brandenburg Mission Conference (1932) and again at the Willingen Mission Conference (1952). Barth was of the opinion that the church should not delegate its mission to mission organisations but should engage in mission itself, because the church is in essence apostolic. The church does not do mission, it is part of God's mission to the world and as such by nature apostolic (Scott 1977:15).

From this understanding of the church and the missio Dei, Geyser (1960:22-23) enters into a sharp criticism of the establishment of ethnic churches via mission organisations or even the church itself. Doing mission at 'an arm's distance' is contrary to the nature of the church and in contradiction to the unity of the church. He rejects the view that church unity is 'invisible'. It is the same criticism of ecclesiastic dualism, the distinction between the 'visible' and 'invisible' church of Christ, which we find in the ecclesiology of Karl Barth (1956, CD IV.1) when he writes:

For that reason the visible and invisible church are not two churches.... The one is the form and the other the mystery of one and the self-same church. The mystery is hidden in the form, but represented and to be sought in it. (p. 669)

This implies that the four attributes of the church are not only applicable to the eternal and invisible church of the confession, but also to the local congregation or church which manifests empirically in history (see also Dreyer 2016:4).

Geyser's ecclesiology as articulated in Vertraagde Aksie is a theological criticism of separate, ethnic churches as well as the church who became a mirror of what was happening in society (Geyser 1960:23). It is extremely dangerous for the church to become 'gelykvormig' (identical) to the world, to reduplicate political structures and ideologies into church practice. It speaks for itself that the publication of Vertraagde Reaksie was met with severe criticism and outright hostility.

Geyser's opposition to apartheid and his criticism of the church's mission policies were some of the factors which led to the charge of heresy. Officially, this has always been denied. However, Geyser's radical opposition to apartheid leaves little doubt that his removal from office would have been important to certain members of the church leadership.

\section{The Cottesloe consultation}

Geyser's theological critique of apartheid is also reflected in his actions leading up to the Cottesloe Conference. Delegates of the WCC and South African member churches convened on 7 December 1960 in Cottesloe, Johannesburg. Discussions during the 7 days focused mainly on race relations in South Africa. The more direct stimulus for the Cottesloe Consultation was the political turmoil in South Africa, for instance the protest marches against the pass system which took place all over South Africa. On the 21st of March 1960 several thousand protesters marched to the police station at Sharpeville, where the leaders of the march intended to burn their passes and hand themselves over to the police for arrest. 
Amidst growing tension the police fired more than 700 shots, wounding 180 people and killing 69. This resulted in a flood of criticism against apartheid from churches and governments all over the world. In the wake of the international community's condemnation of the police actions at Sharpeville and the growing fear that the political unrest may escalate into full-blown civil war.

Civil war was a grim reality in many African states as well as South Africa, especially when the African National Congress launched the armed struggle on 16 December 1961 under leadership of Nelson Mandela - which eventually led to the Rivonia trial (1963-1964) and the imprisonment of Mandela and other leaders of Umkhonto we Sizwe (MK). A state of emergency was declared which increased the powers of state security and made imprisonment without trial possible. It became dangerous to be associated with anti-apartheid activism. From 1960 onwards, after APLA and MK escalated attacks on civil, police and military targets hundreds of activists were arrested, imprisoned or executed. Over a period of 28 years (1961-1989), 134 political activists were executed by hanging after lengthy treason and/or murder trials. Many were 'executed' during covert operations. The number of executions escalated after certain incidents, for instance the Paarl uprising (1963) and the Bethal trials (1977).

The other side of the story also needs to be told. Chapter 4 of the report of the SA Truth and Reconciliation Commission states that MK, APLA and POQO 'committed gross violations of human rights in the course of their political activities and armed struggles, acts for which they are morally and politically accountable' ${ }^{2}$ In the decade 1976 (after the Soweto uprising) to 1986, 130 people were 'executed' by the Black resistance movements, although there might be many more which were not recorded as such. Of these 'executions', 30 were members of various security forces and 100 were civilians. Of the civilians, 40 were white and 60 black. On both sides of the conflict, it became quite dangerous to be regarded as a political activist. Many chose to be silent and stay out of harm's way.

In the light of these events the WCC and South African churches agreed that a consultation of churches would be of extreme importance. During the Cottesloe Consultation churches were asked to condemn apartheid as contrary to Christian principles and unworkable in practice. The Afrikaans churches were not prepared to condemn apartheid as such, but opted for a middle of the road position which asked for justice, a living wage, abolition of job reservation and the act on mixed marriages. The NHKA received extensive reports from its Cottesloe delegates. The General Assembly, on 20 March 1961, decided to terminate its membership of the WCC because of the 'WCC humanistic ideology and support of revolution as well as its double morality' (NHKA 1961c; see Dreyer 2013).

2.See reference at https://www.nelsonmandela.org/omalley/index.php/site/q/03lvo 2167/04lv02264/05lv02335/06lv02357/07lv02372/08lv02376.htm
In context of growing international criticism of apartheid, Dr H.F. Verwoerd led South Africa from the Commonwealth and after a referendum, declared the country a republic. The fires of Afrikaner nationalism burned high. The trauma of the Second Anglo-Boer War, which decimated 20\% of the Afrikaner population in concentration camps and on battle fields, remained engraved in the collective memory. The Afrikaner republic, which was lost with the treaty of Vereeniging on 31 May 1902, was restored on 31 May 1961. Against this background, it became virtually impossible for the Afrikaans churches to disassociate with apartheid. To be against apartheid was regarded as treason to the ideals of liberty and Afrikaner nationalism.

In this atmosphere of state controlled security, rising nationalism, political unrest and the possibility of civil war Geyser's public resistance to apartheid and his positive attitude towards the WCC, is quite remarkable. It was also the case with Geyser's involvement with and positive assessment of the Cottesloe Consultation, as is evident in the Memorandum he and Prof. Adrianus van Selms submitted to the Moderature of the NHKA (Geyser \& Van Selms 1960b). This was accompanied by a letter, dated 23 November 1960 (Geyser \& Van Selms 1960a), in which they requested the Moderature to submit their Memorandum together with the church's official documents to the Cottesloe Consultation. The Moderature refused their request.

The Memorandum Geyser and Van Selms prepared for the Cottesloe Consultation is structured on different 'levels', as they called it (Geyser \& Van Selms 1960b:28 [1]). It starts out with an analysis of South African demographics (3 million whites, 1.5 million mixed race people, half a million 'Asiatics' and 10 million 'Bantu' of whom $62 \%$ lived in so-called 'white' areas) and points out that the policy of apartheid would require the forcible removal of 6 million people without their consent or approval. Forcible removal constitutes gross injustice and is a sign of 'selfishness and self-righteousness' (Geyser \& Van Selms 1960b:29 [2]). The Memorandum concludes this section by pointing out that apartheid is not only an injustice to all 'Non-White' people of South Africa, but in view of long term economic development and population growth it is untenable and impractical. We submit therefore that apartheid is and will of necessity be in the future, a total failure. All the hardships, injustices and injuries it inflicts in the meantime would have been of no effect except that it would have aggravated the legacy of suspicion and hatred for future generations.

Secondly, the Memorandum of Geyser and Van Selms articulated the meaning of the gospel for race relations in South Africa. With reference to the WCC views it explains that any form of segregation based race or ethnic origin is contrary to the gospel and incompatible with the Christian doctrine of man and with the nature of the Church of Christ (Geyser \& Van Selms 1960b:31 [4]). Geyser and Van Selms point out that the church must 'first and of all accept the unequivocal and unanimous teaching of the Bible that the 
Church must be visibly one in testimony to Christ, in faith, love and personal communion (John 17)'. Following this argument, Geyser and Van Selms rejected the establishment of ethnic churches in South Africa as practised by practically all the churches in South Africa at that time.

Thirdly, Geyser and Van Selms enters into a discussion of contemporary history and developments in Africa and how it challenged our understanding of freedom, responsibility, justice and order (Geyser \& Van Selms 1960b). In this regard the Memorandum states:

the Church must not take a neutral or even less, an opposing stand. Within this process of political and social awakening, the Church must act as the conscience of the nation ... (p. 34 [7])

Further in this section it is pointed out that 'the rule of law in every country must exclude the arbitrary use of power by one group to the detriment of another'. It continued to plead for the freedom of the press, the right to political selfdetermination, distinction between legislative, administrative and executive powers, freedom of moral and religious convictions in obedience to God.

Lastly, Geyser and Van Selms analysed the different apartheid laws and criticised the Church for being silent on the implications and effect of many of these laws (Geyser \& Van Selms 1960b:32-34 [9-11]).

Geyser and Van Selms' Memorandum on apartheid is a substantial document, well formulated in terms of practical, religious, political and moral arguments. It is a pity that it was never considered seriously or presented to the Cottesloe Consultation of the WCC. Its severe criticism of apartheid on moral and religious grounds caused a major break in relations between Geyser, the Moderature of the NHKA, colleagues at the Faculty of Theology and the church in general. Geyser had become an isolated figure and persona non grata. He became a public enemy, often portrayed by the press as villain or as hero. Hundreds of articles appeared in newspapers reporting on Geyser and the other clergy's opposition to apartheid (see Labuschagne 2014). Geyser was regarded as a traitor and a threat to Afrikaner nationalism, the reason many wanted him removed from the Faculty of Theology at the University of Pretoria.

\section{The heresy trial of Albert Geyser}

On 5 October 1961 Benjamin Pogrund broke the news in the Rand Daily Mail that a charge of heresy had been laid against Geyser (Labuschagne 2014 Vol. I:10). The charges were laid by three senior theological students. Geyser's immediate response to the Rand Daily Mail was to be expected: The charge of heresy was without 'any basis of fact'. Geyser was deeply shocked by the fact that his own students laid a charge of heresy against him. He denied that he was a heretic and made it clear that he wanted to defend himself on the charges (see Dreyer 2015:191).
The three senior students who laid the charge of heresy against Geyser, were H.G. van der Westhuizen, W.C.M. de Beer and E. Engelbrecht (NHKA 1961a:98). Over a period of time, each of them took careful notes during class of Geyser's lectures. The charges against Geyser were based on his theology and exegesis as articulated during lectures (see NHKA 1961a). Copies of these class notes still exist but can only be viewed with permission. The lectures in question were presented by Geyser during 1961 on 17 April, 21 April, 18 May, 23 May, 12 June, 18 August, 25 August and 14 September. It was common practice to dictate lectures, in other words, students had to write down everything which was said in class because it formed the basis of examination. Interestingly enough, the charge sheet also affords us a little insight on the quality and extent of the lectures of Geyser. Geyser used the Greek New Testament as basis for his lectures, with a strong focus on linguistic analysis of the Greek text. As a result, the charge sheet contains numerous Greek passages with a critical analysis of what Geyser said in class. Geyser also combined exegesis with theological reflection. After a specific text was analysed with regard to language and structure, the theological implications would be spelled out. According to the charge sheet, Geyser referred in his lectures to the early philosophers (Seneca) and the Church Fathers (p. 1, 7, 8, 10), John Calvin (p. 2), the Heidelberg Catechism (p. 8) as well as contemporary theologians such as Karl Barth (pages 1,4) and prominent ecumenical theologians such as Natan Söderblom (p. 6) and Robert Bilheimer (p. 9).

The heresy trial lasted almost 6 months. It started on 24 October 1961 and adjourned on 8 May 1962 when the findings of the Moderature were announced. The trial adjourned over the Christmas holidays and other periods in which the Moderature attended to other business and because Geyser became ill. The minutes of the trial consists of 2672 typed pages divided into five volumes (NHKA 1961b) of approximately 500 pages each. The page numbers follow in sequence from 1 to 2672 , which indicates that the trial was regarded as one meeting, although there were times in which the Moderature was not in session.

Turning the charge sheet (NHKA 1961a) per se, the 10 pages contain two main charges against Geyser: The first was a charge of heresy and the second a charge of resistance to ecclesial authority. The two charges were subdivided into five sections, namely Christology, Ecclesiology, Anthropology, Pneumatology and insubordination/resistance/disobedience to ecclesial authority and synodical decisions. The five sections were further divided into 20 subsections.

\section{Christology}

The charge of heresy starts out with Geyser's Christology as articulated in his lectures on the Paul's Letter to the Philippians (p. 1). On 18 August 1961 Geyser discussed Philippians 2. The main question was how the Greek word morphe (Phlp 2:6) should be translated and interpreted. After explaining the different possibilities in translation, 
Geyser referred to the Church Fathers who translated it as substantia and Karl Barth who translates it as Gestalt. Geyser explained that morphe could also be translated as status. If 'morphe' is translated as 'status', it would mean that the pre-existent Christ had divine status, but would not necessarily be equal to God the Father.

Geyser disagreed with the traditional translation of morphe as substantia or ousia, as is done by many systematic theologians as proof of Christ's divine nature. He was of the opinion that this translation needed to be revised (p. 2). What is reflected in the charge sheet, is a typical New Testament scholar at work: Geyser engaged with text of the New Testament in a scientific way. Precise linguistic analysis was elucidated with exegetical examples from history and various ecclesial traditions. It is also clear that Geyser exposed the students to the diverse Christologies as articulated in the New Testament as well as the writings of the Early Fathers. However, this did not imply that he rejected the traditional Christology and divinity of Christ as articulated in the Nicene Confession (p. 3). His view was that Philippians 2 could not be used to substantiate the equality of the first and second Persons of the Trinity.

The charge sheet continued to criticise Geyser's views on the meaning of what it means to be in Christ (Phlp 1:1), to love your neighbour unconditionally (agape, Phlp 1:9), Christ as example to us (Phlp 2:5) and a 'holy revolution' (p. 5, 'heilsrewolusie'). It is clear that the charge wished to indicate that Geyser maintained a humanistic Christology in which Jesus would be little more than a good moral example of how we should live and as such confirmed that Geyser's Christology was contrary to the reformed confessions. Reading it many years later, it seems that Geyser merely articulated the ethical implications of Christian faith without denying the divinity of Christ.

\section{Ecclesiology}

The same argument is followed in the section on Geyser's ecclesiology. In his lecture on Philippians 2:4 Geyser explained that koinonia with fellow-believers could not be dislocated from our community with God. Rather, community with God constitutes community among all believers and is the guarantee that God will never leave his church. In his lecture on 1 Corinthians 10:17 Geyser made a point about Paul's understanding of the Eucharist and the visible unity of the church. In his lecture Geyser also referred to Ignatius' Letter to the Philippians in which he explains the unity of the church which becomes manifest in the Eucharist. The charge sheet is particularly worried about Geyser's positive evaluation of the WCC (p. 6) and his view that the church had to engage the world wherever the world is 'sick' (i.e. Angola, Korea - war zones at the time). Geyser also pleaded for social justice (again with reference to Ignatius' letters to the Philippians and Trallians), which would indicate that he was a proponent of social gospel. Lastly, Geyser is also criticised for his positive assessment of the Anglican Book of
Common Prayer as excellent theology, which gave rise to the suspicion that Geyser had an affinity not only for Anglican but also for Roman Catholic theology. It is clear that Geyser's positive stance on visible church unity, the ecumenical movement and social justice was regarded as blasphemy in a period when segregation reached its zenith.

\section{Anthropology}

In his lecture on Philippians 2:3 he discussed the question of human dignity, again with reference to the views of Karl Barth (p. 7). Geyser quoted Barth's view that all human beings should be regarded as objects of God's grace which implies that we should regard fellow human beings with 'limitless respect'. The real problem arose during a lecture on 12 June 1961, when Geyser discussed the imago Dei. He made the remark that the image of God was not totally destroyed in man which was regarded by the students as contrary to the Heidelberg Catechism III/6. Interestingly enough, Geyser's view corresponds to that of John Calvin as articulated in his Institutes of Christian Religion (Inst. III/7/6; Calvin [1559] 1864).

\section{Pneumatology}

The charge sheet refers to Geyser's discussion of the Heidelberg Catechism 1/1 and our only comfort in life and death (p. 8). Geyser made the point that the Holy Spirit assures us of eternal life through our knowledge of sin, salvation and how we should thank God for our salvation. The criticism as articulated in the charge sheet does not address Geyser's Pneumatology as such, but rather Geyser's reference to Seneca 'who could teach Christians how to live and in fact put Christians to shame in terms of morality'. The implication is clear: Geyser was of the opinion that Seneca had more to offer than the Bible or even the Holy Spirit.

Geyser also pointed out that faith and life is the same thing without ethical actions and a Christian lifestyle there is no faith. This is a theme already evident in Geyser's early theological development, especially with his translation of the De Imitatio Christi (Geyser 1952). 'Heresy' in this section is implied in Geyser's view that true Christian faith needs to be realised in a Christian life and love for humanity - in other words - a humanistic interpretation of the gospel.

\section{Resistance to ecclesial authority}

In the last section of the charge sheet Geyser is taken to task for his criticism of the church, for instance his view that the church is too dogmatic in its exegesis (p. 9). Exegesis should be determined by a 'precise determination of the meaning of the Greek words' ('korrekte bepaling van die woord betekenis'). Geyser was an exponent of historical-critical exegesis and regarded literary exegesis as more important than 'dogmatic' exegesis. The implied allegation is that Geyser undermined the authority of the reformed confessions, although it is not articulated expressis verbis. In this way, Geyser 'influenced' students against the church. 
The real issue appears in the last section: Geyser expressed himself in favour of the Cottesloe Consultation and asked the students if they wanted to meet Dr. Robert Bilheimer, to listen to his viewpoint. This would be, according to Geyser, an academic and scientific approach to listen to all viewpoints. Geyser also criticised the selective inequality as practiced in South Africa and equated it to 'Communism and slavery' ( $\mathrm{p}$. 10). Confronting students with these views put the church in a bad light. Geyser was charged with undermining the authority of the church, the Church Order and policies as approved by the General Assembly.

\section{Evaluation}

Looking at the charge of heresy and resistance to ecclesial authority, one is struck by the almost artificial construction of theological arguments, but even more the obvious criticism of Geyser's socio-political views. Reading texts is very often a question of finding the true intention of the author not in what is written, but rather in what is not written, in the empty spaces between the lines. In the heresy trial of Geyser the real issue, his criticism of apartheid and separate ethnic churches, is never mentioned explicitly except for a cursory reference to Article III of the Church Order which envisaged the establishment of racially segregated churches (p. 10).

\section{Geyser found guilty of heresy}

The deliberations of the Moderature on the heresy charge against Albert Geyser came to a conclusion on 8 May 1962, when the findings were made public (NHKA 1962:1-18). The findings follow the same structure as the charge laid against Geyser. It is quite significant that Geyser was found not guilty on all charges related to his Ecclesiology, Pneumatology, Anthropology and resistance to ecclesial authority. In fact, the charge of heresy with regard to his Anthropology doesn't even appear in the findings. Regarding Geyser's Christology, no reference is made to Geyser's exegesis in terms of 'being in Christ', 'unconditional love' or Christ as 'example'. In summary: The charge sheet consists of 20 sub-sections under the various headings, of which the Moderature rejected 19. Geyser was found guilty only in terms of the very first section, which focused on his exegesis of Philippians 2:6-11.

After introductory remarks on procedure and the relevant articles of the Church Order, the Moderature turned to the charge of heresy regarding Geyser's Christology (p. 2). The Moderature condensed the charge and 2672 pages of minutes into one single aspect, namely Geyser's lectures on Philippians 2:6-11 which, according to the supplicants, accommodated the view that Christ before and after His incarnation, in terms of status, was subordinate to God the Father and that the post-existent Christ was of higher status than the pre-existent Christ. This was in contradiction to the pure doctrine as articulated in confessions, especially the Athanasium.

The Moderature points out that in his defence Geyser placed much emphasis on three aspects: (1) The freedom of the exegete; (2) the precise exegesis of Philippians 2:6-11 and (3) the charge was instigated and motivated by external agents and as such without substance or legal standing (NHKA 1962:3). These three points of the defence were discussed extensively and attended to in the findings. On point 2 of the defence, the Moderature readily acknowledged the skill and expertise of Geyser as Biblical scholar and exegete of Scripture. On point 3, the Moderature was of the opinion (pp. 14-15) that it would be impossible to determine whether there were external agents who instigated the charge of heresy and that the Moderature had to assume the integrity and good intentions of all involved.

The charge of heresy against Geyser boiled down to three interrelated questions: The freedom of the exegete (pp. 3-8), the binding of the exegete to the confessions and doctrine of the church and whether Geyser, in his exegesis and lectures on Philippians 2, entertained a subordianistic Christology (pp. 8-14). The Moderature found Geyser guilty of heresy (dwaalleer) and suspended his status and privileges as minister of the NHKA.

At various (23) times during the heresy trial Geyser made a point to declare his unconditional agreement with the confessions of the church. His exegesis of Philippians 2:5-11 is in agreement with other New Testament scholars, namely that it could not be used to substantiate the doctrine of the Trinity. Despite this, he was convicted of heresy.

After the trial, Geyser received an offer from the University of the Witwatersrand to take up a position as professor in the Department of Religious Studies, which he accepted in 1962. In 1963 he resigned his office as minister of the NHKA and in 1968,50 years old, he resigned his membership of the NHKA. However, before he died in 1985 he expressed the desire to be buried by a minister of the NHKA. In accordance with his last wish his funeral was conducted by Dr. Joop Lensink, also known for his opposition to apartheid.

\section{Media coverage of the trial ${ }^{3}$}

As mentioned before, the Rand Daily Mail broke the news on 5 October 1961 that a charge of heresy had been laid against Geyser (Labuschagne 2014 Vol. I:10). ${ }^{4}$ This started a media frenzy. In London, the Daily Mail (12 October 1961; Vol. I:13-14) published an article based on telephonic interviews it had had with four well-known Dutch theologians: Prof. P.A. van Stempvoort (Groningen), Hendrikus Berkhof (Leiden), J.N. Barkhuizen van den Brink (Leiden) and B. Gemser (emeritus of the University of Pretoria living in Groningen). They were unanimous in

3.Some sections of this paragraph had been published previously (see Dreyer 2015).

4.The newspaper clippings used in this contribution were collected and bound in three volumes by Prof. Casper Labuschagne, co-activist, colleague and friend of Albert Geyser. The collection starts in 1960 and ends in 1968. Prof. Labuschagne Albert Geyser. The collection starts in 1960 and ends in 1968. Prof. Labuschagne entrusted his collection to me in 2014 when I visited him in Groningen. On my return I deposited copies of these volumes (totalling 400 pages and approximately 900 newspaper articles) in the archives of the DRC as well as the Ned. Hervormde Kerk van Afrika (NHKA). The unpublished volumes of newspaper clippings will b referenced (in example) as 'Labuschagne 2014 Vol. I': with page number and if known, the original author. In most instances the author is indicated only as 'Staff Reporter'. 
their condemnation of the heresy charge, calling Geyser one 'of the most brilliant theologians of South Africa' whose credentials and credibility were impeccable. They were unanimous in their view that the charge of heresy against Geyser was politically motivated, orchestrated by the Afrikaner Broederbond and devoid of all theological substance. Two days later the Rand Daily Mail also carried a report on Rabbi B. Isaacson who called Geyser a 'Noah of this generation' during a sermon he delivered in the Krugersdorp Synagogue. He found Geyser's actions 'inspiring and refreshing', a man who did not sacrifice his principles on the altar of expediency.

The heresy charge against Geyser coincided with a vote in the United Nations which censured South Africa (Vol. I:15). The Sunday Times reported (15 October 1961) that a major crisis was looming in relations between the Netherlands and South Africa, under the heading 'Grave crisis in S.A. Holland relations'. According to the Sunday Times reporter, the 'grave crisis' was precipitated by two factors, namely the Netherlands who had been the only European country to vote with the Afro-Asia block in the United Nations to censure South Africa, and secondly the severe and public condemnation by the Nederlandse Hervormde Kerk of the charge of heresy against Geyser. The general feeling expressed by Prof. Hendrikus Berkhof was that normal relations with the NHKA had become impossible. In the same statement the Dutch church expressed its support for the decisions of the United Nations. The Geyser trial again surfaced at the United Nations on 8 November, when the South African minster of Foreign Affairs, Mr. Eric Louw, was called to address the UN Commission on the issue (Transvaler, 9 November 1961 Vol. I:48).

At least 25 national and international newspapers had reporters on standby at the church offices, but they were denied access to the trial. The area around the offices was packed with interested members of the public, who were also denied entry except if they were members of the NHKA. So many members of the church attended the trial that they had to sit on the floor in a hall which could seat 450 people (Vaderland, 25 October 1961 Vol. I:26). On the day the trial started, the Utrecht Theological Faculty sent an official telegram to the Pretoria Faculty of Theology to do their utmost to stop the trial (The Star, 24 October 1961 Vol. I:19). It was followed by a telegram from the Praeses of the Dutch General Synod delivered to the Moderature of the NHKA, imploring them not to take any decisions which would jeopardise the Reformed principles of the church. Telegrams of support were sent to the Geyser home, including from several theological faculties such as Groningen and Pittsburgh Theological Seminary, which invited Geyser to apply for a position (Vol. I:50).

Newspapers carried reports on a daily basis in which the trial's progress was described. Personal profiles of Geyser, Mrs Celia Geyser (who confirmed her support of her husband's views), his father, students who accused Geyser of heresy as well as the members of the Moderature were published. Geyser was depicted as a staunch Hervormer with an Afrikaner lineage going back two centuries. The Rand Daily Mail (24 October 1961) writes:

Born and brought up in the fervent tradition of Afrikaner nationalism, the descendent of an early Trekker family, a brilliant and highly-regarded theologian in a conservative church, now a self-admitted crusader against the intolerances and abuses of nationalism ... (Vol. I:18)

It continues to describe how deeply Geyser had been influenced by books he read on the struggle of Christianity against Nazism in Germany and his growing conviction that Christianity, nationalism and authoritarianism could never be reconciled.

The Transvaler (9 May 1962) published the verdict of the heresy trial in toto (Vol. I:57). The newspaper's emphasised aspects of the findings of the Moderature, for instance that Geyser was reckless in the way he confronted the students in class with different interpretations of Scripture, some contrary to the confessions, to such an extent that students' faith was undermined. The Rand Daily Mail (10 May 1962) summed up the events in a main editorial under the heading Heretic or rebel? And then continues:

The 'trial' of Dr Albert Geyser, Professor of New Testament Theology at the University of Pretoria and minister of the Nederduitsch Hervormde Kerk, on charges of heresy and insubordination has been one of the most extraordinary events of recent years in South Africa and the outcome has been equally remarkable ... if he had been a political conformist, his theological views would never have been questioned ... Dr. Geyser has been pilloried for his moral stand on race questions - whatever has been decided against him on theological grounds. (Vol. I:62).

After the trial and Geyser's removal from office, he received more than a thousand letters of support from all over the world. He received several invitations to deliver speeches and to preach in various churches. The Pretoria News reported that Geyser, during a sermon (on the text of Hebrews 5:8) in the Congregational Church of Pretoria, told the congregation 'that a church which has no compassion with suffering, irrespective of race or creed, has lost its Christianity ...' (Labuschagne 2014 Vol. II:1). Christians needed to be brave in the face of threats and intimidation, probably referring to the fact that he received several death threats, abusive phone calls and letters condemning his views.

On 16 May 1962 the Rand Daily Mail reported that Prof. Adrianus van Selms resigned his position as professor of Old Testament at the University of Pretoria as a protest against the verdict against Geyser. In his letter of resignation he states: 'Conscience forbids me to allow any human being to dictate to me what the Divine Word says' (Vol. II:2). The theme of justice, human dignity and conscience was also the main focus of a lecture which Geyser delivered to a packed hall of between 1600 and 2000 students on the campus of the Witwatersrand University (Pretoria News, 16 May 1962). Geyser pointed out that the lack of human 
dignity in South Africa was leading the country to its destruction. South Africa, he said, was prepared to hang a man because he tries to protect human dignity. Without the concept of justice and human dignity there is no civilisation. South Africans have become 'mental acrobats', turning justice into self-righteousness, love into self-love and respect for life into self-preservation.

Following the conviction of Geyser and the resignation of Van Selms, other lecturers also came under fire. The Sunday Times reported (30 September 1962) that Dr Casper Labuschagne, a 'new deal' theologian, had been dismissed as lecturer in Biblical Studies at the University of Pretoria because, it was believed, he was an ally of Geyser and a critic of apartheid. Labuschagne challenged the decision but was informed that it was a 'practical' arrangement due to the change in the structure of the theological curriculum (Dagbreek, 14 October 1962 Vol. II:7). Five years later Labuschagne relocated to Groningen where he was appointed as lecturer and later professor of Old Testament.

\section{The Geyser verdict overturned in the Supreme Court}

Geyser appealed his conviction of heresy in the Supreme Court of South Africa. The case started on 1 May, 1963. Geyser asked the court, under presiding judge J.F. Ludorff, to set aside his conviction of heresy. Geyser's argument in court was that the findings of the heresy trial should be set aside because the members of the commission were biased, acted male fide and the process was fraught with irregularities. During the trial Geyser confirmed his faith in the Triune God as articulated in the confessions.

On 14 May the hearing was postponed, to give the parties an opportunity to come to some agreement. On 15 May 1963 the trial ended dramatically, when the court heard that Geyser had been restored to his office as minister of the NHKA (Dreyer 2015:195). The church undertook to pay all legal fees. The Commission of the General Assembly (Moderature) also declared publicly that it had made a 'bona fide and unintentional mistake' in the interpretation of Geyser's viewpoints. It is clear the church realised it would lose the court battle. In one passage of his unpublished 'Memoirs', Judge Frik Eloff (Geyser's legal advisor at the time of the heresy trial) wrote:

Na ongeveer twee weke van verhoor was dit redelik duidelik dat die Hervormde Kerk op die afdraande pad was. Op 'n dag nader Adv. Tienie de Kock ons om te verneem of die verhoor vir 'n wyle kan oorstaan sodat 'n skikking bespreek kan word. Ons het ingewillig, en Tienie versoek regter Ludorff om tyd af te staan sodat " $n$ broederlike samespraak' kan geskied. Die Regter het ingestem, en ons het in die kantore van die Hervormde Kerk vergader. Sy eerste voorstel was dat Geyser as predikant herstel word. Ons antwoord was "n duidelike 'nee', Geyser moet nie herstel word nie; die Kerk moet instem tot ' $n$ bevel dat Geyser se skuldigbevinding aan kettery van meet af nietig was. En die Kerk moet al sy gedingskoste, op die skaal van prokureur/ kliënt, betaal. (Eloff n.d.)
According to Eloff, the conviction of Geyser on the charge of heresy was declared null and void, as if it did not happen. Geyser was reinstated as minister of the NHKA and in his position as lecturer at the University of Pretoria and the NHKA had to pay all the legal fees. Although Geyser was vindicated by the court, it was still not the end of the saga. Although Geyser resigned as minister of the NHKA he remained a member of the church until 1968, after a second court battle in which Albert Geyser and Beyers Naude sued Prof. A.D. Pont for libel. The court found Pont guilty of libel and he had to pay damages to Geyser and Naude. That history still needs to be written.

\section{Conclusion}

Public theology could be regarded as theology engaged in social, political and practical issues of the day. Mannion (2009:122) is of the opinion that the 'best public theology involves theological hermeneutics in the service of moral, social and political praxis'. Bromell (2011:15) is of the opinion that public theology is 'critical thinking about faith and public life'. In public theology questions of ethics, ecclesiology and integrity are of constant importance. This was illustrated to the point in Nazi Germany by theologians like Dietrich Bonhoeffer and Karl Barth as well as the Barmen Declaration which became a classic text of public theology (Mannion 2009:137). The Belhar Confession could also be included in this line of classical texts.

Public theology is neither political activism nor ideology clothed in the robe of Christian faith. Public theology reflects on socio-political issues from a sound theological perspective and relies on proper Biblical exegesis. For that simple reason many of the famous theologians since the Early Church could be regarded as 'public theologians'. Augustine, Aquinas, Hus, Luther, Calvin, Bonhoeffer, Barth, Moltmann - and many more - could be considered 'public theologians', precisely because they were excellent theologians and students of Scripture. It requires a fundamental understanding of the gospel, moral sensitivity, sound knowledge of history, a fair amount of bravery and insight into the complexities of current socio-political issues to be a public theologian who could contribute substantially to the well-being of church and society.

Albert Geyser was such a theologian. He was convinced that the gospel of Jesus Christ was of immense importance to society. To follow Jesus Christ (Mk 8), requires of every Christian and the church to bear a cross and to lay down your life for others.

\section{Acknowledgements Competing interests}

The authors declare that they have no financial or personal relationships which may have inappropriately influenced them in writing this article. 


\section{References}

Barth, K., 1956, Church Dogmatics Vol. IV/1, edited by G.W. Bromiley \& T.F. Torrance and translated by G.T. Thomson \& H. Knight, T \& T Clark, Edinburgh.

Bromell, D., 2011, 'What is public theology?' Unpublished lecture delivered at Otago University, May 2011, viewed 21 March 2016, from http://www.otago.ac.nz/ctpi/ otago032508.pdf

Calvin, J., [1559] 1864, 'Institutio Christianae Religionis', in G. Baum, E. Cunitz \& E. Reuss (eds.), Corpus Reformatorum Vol. XXX loannis Calvini opera quae super suntomnia Volumen II, C.A. Schwetsschke et Filium, Brunsvigae.

Dreyer, W.A., 2013, 'Fifty years of isolation: The Nederduitsch Hervormde Kerk 1960-2010', in M.A.P. van Huffel \& R. Vosloo (eds.), Reformed Churches in South Africa and the struggle for justice. Remembering 1960-1990, pp. 133-142, Sun Media, Stellenbosch.

Dreyer, W.A., 2015, 'In pursuit of justice: Albert Geyser's story as told by the media', Studia Historiae Ecclesiasticae 41(3), 184-197.

Dreyer, W.A., 2016, 'Church, mission and ethics. Being church with integrity', HTS Teologiese Studies/Theological Studies 72(1), a3163. http://dx.doi.org/10.4102/ Teologiese Studies/
hts.v72i1.3163

Eloff, F., n.d., 'Memoirs', unpublished.

Geyser, A.S., 1952, Die Navolging van Christus, H.A.U.M., Kaapstad.

Geyser, A.S., 1960, 'Die Eerste Evangelie oor die eenheid van die kerk as Christusgetuienis', in A.S. Geyser \& B.B. Keet (ed.), Vertraagdeaksie: 'n Ekumeniese getuienis vanuit die Afrikaanssprekende kerk, pp. 5-11, published by the editors, Pretoria.

Geyser, A.S. \& Van Selms, A., 1960a, 'Brief aan die Algemene Kommissie 23 November 1960', in Handelinge van die Kommissie van die Algemene Kerkvergadering Januarie 1960 tot Desember 1960 Deel V, p. 28, NHKA Archives, Pretoria.
Geyser, A.S. \& Van Selms, A., 1960b, 'Memorandum', in Handelinge van die Kommissie van die Algemene Kerkvergadering Januarie 1960 tot Desember 1960, pp. 28-40 (1-11 of memorandum), NHKA Archives, Pretoria.

Labuschagne, C., 2014, Geyser newspaper clippings, vols. I, II \& III, NHKA Archives, Pretoria.

Mannion, G., 2009, 'A brief genealogy of public theology, or doing theology when it seems nobody is listening', Annali di Studi Religiosi 10, 121-154.

NHKA, 1961a, Klagskrif, Handelinge van die Kommissie van die Algemene Kerkvergadering, 24/10/1961, NHKA Archives, Pretoria, pp. 89-98.

NHKA, 1961b, Notule Geyser-verhoor, Handelinge van die Kommissie van die Algemene Kerkvergadering, vols. I, II, III, IV \& V, (25/10/1961-4/4/1962), NHKA Archives, Pretoria, pp. 1-2672.

NHKA, 1961c, Notule van die Algemene Kerkvergadering, NHKA Archives, Pretoria.

NHKA, 1962, Handelinge van die Kommissie van die Algemene Kerkvergadering $8 \mathrm{Me}$ 1962, Bevindinge en uitspraak met betrekking tot die klag teen Prof A.S. Geyser, NHKA Archives, Pretoria, pp. 1-18.

Oberholzer, J.P., 2010, 'Politieke spanning en ekumeniese druk 1954-1960', in 'Honderd Jaar Kerken Teologiese Opleiding: ' $n$ Kroniek van die Hervormde Kerk', HTS Teologiese Studies/Theological Studies suppl. 9, 66(3), Art. \#920, 1-10. http:// dx.doi.org/104102/hts.v66i3.920

Scott, W., 1977, Die Missionstheologie Karl Barths, BrunnenVerlag, Basel.

Sowetan Live, 2015, Some whites deserve a statue, viewed n.d., from http://www. sowetanlive.co.za/incoming/2015/05/01/some-whites-deserve-a-statue

Van Aarde, A.G., De Villiers, P.G.R. \& Buitendag, J., 2014, 'The forgotten struggle of Albert Geyser against racism and apartheid', HTS Theological Studies 70(1), Art. \#2820, 1-10. http://dx.doi.org/10.4102/hts.v70i1.2820 